\title{
Hockey puck sign: identifying Moraxella catarrhalis
}

\author{
Yasuhiro Kano
}

Department of Internal Medicine, National Hospital Organisation Tochigi Medical Center, Utsunomiya, Tochigi, Japan

\section{Correspondence to} Dr Yasuhiro Kano; yasuhiro.kano.21@gmail.com

Accepted 22 April 2021
D) Check for updates

(c) BMJ Publishing Group Limited 2021. No commercial re-use. See rights and permissions. Published by BMJ.

\begin{tabular}{|l|}
\hline To cite: Kano Y. BMJ Case \\
Rep 2021;14:e243677. \\
doi:10.1136/bcr-2021- \\
243677 \\
\hline
\end{tabular}

\section{DESCRIPTION}

A 76-year-old male patient with diabetes mellitus presented with a 4-day history of productive cough and fever. He was a former smoker, with a history of smoking 30 packs of cigarettes per year. Physical examination revealed the following: body temperature, $38.6^{\circ} \mathrm{C}\left(101.5^{\circ} \mathrm{F}\right)$; heart rate, 115 beats $/ \mathrm{min}$; blood pressure, 136/82 $\mathrm{mm} \mathrm{Hg}$; respiratory rate, 22 breaths/min and oxygen saturation, $96 \%$ on room air. Slight crackles were detected by auscultation over the right lower zone of the lung. CT showed mixed interstitial-alveolar infiltration of the right lower lung without emphysema. A sputum Gram stain revealed abundant, Gram-negative diplococci (figure 1A), and empiric therapy with ceftriaxone was begun. On hospitalisation day 2, the culture grew round colonies on blood agar and chocolate agar which slid across the agar surface without disruption (ie, the hockey puck sign, figure $1 \mathrm{~B}$ and video 1 ). Based on these clinical and microbiological findings, ceftriaxone was continued, and the symptoms quickly resolved. Subsequently, the organisms were identified as Moraxella catarrhalis using the VITEK 2 system (BioMérieux, France).

M. catarrhalis is a common pathogen in respiratory tract infections. In adults, $M$. catarrhalis pneumonia occurs most frequently in elderly patients with an underlying illness, such as cardiopulmonary disease, chronic kidney disease and diabetes mellitus. ${ }^{12}$ To treat $M$. catarrhalis infections, extended-spectrum cephalosporins, ampicillin/sulbactam or amoxicillin/ clavulanic acid are recommended because M. catarrhalis often produces beta-lactamase and may be resistant to penicillin, ampicillin and amoxicillin. Prompt identification of the causative organism is essential for pneumonia management, for which the findings of the sputum Gram stains and culture can provide practical data. However, M. catarrhalis morphologically resembles Neisseria spp, which are also part of the normal,

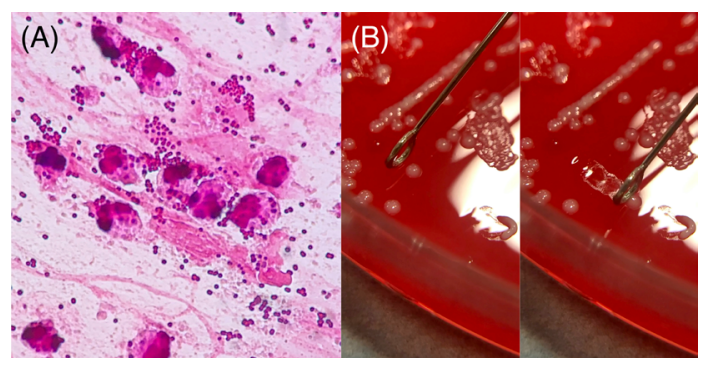

Figure 1 (A) Sputum Gram stain showed neutrophils and Gram-negative diplococci resembling Moraxella sp or Neisseria sp. (B) The colonies were able to be slid across the agar surface without disruption, a feature known as the 'hockey puck sign'.

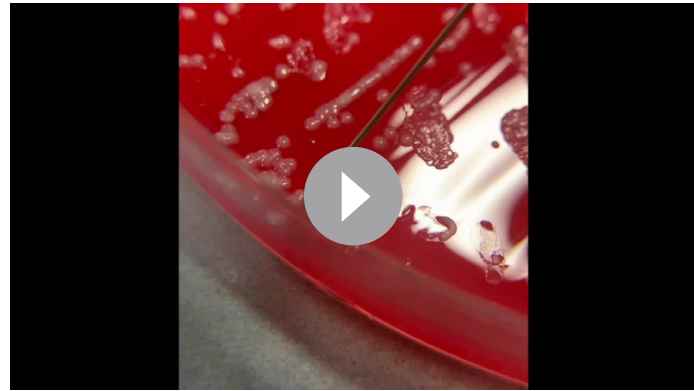

Video 1 The colonies were able to be slid across the agar surface without disruption, a feature known as the 'hockey puck sign'.

\section{Learning points}

- Moraxella catarrhalis is a common, bacterial cause of pneumonia most frequently occurring in elderly patients with an underlying illness.

- A characteristic feature of $M$. catarrhalis colonies is their ability to be slid across the agar surface without disruption, known as the 'hockey puck sign'.

- A combination of sputum Gram stain examination and the hockey puck sign leads to prompt diagnosis and treatment of $M$. catarrhalis infection in patients with pneumonia.

upper airway flora. The hockey puck sign is therefore useful in distinguishing M. catarrhalis from Neisseria spp.

Acknowledgements The author thanks James R. Valera and Kei Karakida for their assistance with editing the manuscript.

Funding The authors have not declared a specific grant for this research from any funding agency in the public, commercial or not-for-profit sectors.

Competing interests None declared.

Patient consent for publication Obtained.

Provenance and peer review Not commissioned; externally peer reviewed.

\section{ORCID iD}

Yasuhiro Kano http://orcid.org/0000-0003-1210-2859

\section{REFERENCES}

1 Hirai J, Kinjo T, Koga T, et al. Clinical characteristics of communityacquired pneumonia due to Moraxella catarrhalis in adults: a retrospective single-centre study. BMC Infect Dis 2020;20:821.

2 Wright PW, Wallace RJ, Shepherd JR. A descriptive study of 42 cases of Branhamella catarrhalis pneumonia. Am J Med 1990;88:S2-8.

3 Murphy TF. Haemophilus and Moraxella Infections. In: Kasper DL, Fauci AS, Hauser SL, et al, eds. Harrison's Principles of Internal Medicine. 19th ed. New York: McGraw-Hill Education, 2015: 1010-4. 
Images in...

Copyright 2021 BMJ Publishing Group. All rights reserved. For permission to reuse any of this content visit https://www.bmj.com/company/products-services/rights-and-licensing/permissions/

BMJ Case Report Fellows may re-use this article for personal use and teaching without any further permission.

Become a Fellow of BMJ Case Reports today and you can:

- Submit as many cases as you like

Enjoy fast sympathetic peer review and rapid publication of accepted articles

Access all the published articles

Re-use any of the published material for personal use and teaching without further permission

Customer Service

If you have any further queries about your subscription, please contact our customer services team on +44 (0) 2071111105 or via email at support@bmj.com.

Visit casereports.bmj.com for more articles like this and to become a Fellow 